\title{
Animal Oppression and Solidarity: Examining Representations of Animals and Their Allies in Twenty-First Century Media
}

\author{
TAYLER ZAVITZ, University of Victoria
} CORIE KIELBISKI, University of Victoria

\begin{abstract}
Popular media, both literature and film, provide a location in which animal suffering, resistance and solidarity are finally visible. An examination of Bong Joon-ho's award-winning film Okja (2017) and Karen Joy Fowler's New York Times best-selling novel We Are All Completely Beside Ourselves (2013) reveals complex media representations of animals that highlight the significance of twenty-first century media in depicting the animal in the human world.
\end{abstract}

\section{KEYWORDS}

Animals, Media, Liberation, Anthropocentrism, Activism

\section{Introduction}

Through a critical animal and media studies (CAMS) framework, this paper analyses media representations of animals ${ }^{1}$ in Bong Joon-ho's award-winning film Okja (2017) and Karen Joy Fowler's New York Times best-selling novel We Are All Completely Beside Ourselves (2013). Both reveal complex depictions of animals that highlight the significance of twenty-first century media in portraying the animal in the human world. We will first assess the portrayals of human and animal relationships in these media sources, with attention to how the animal protagonists have been individualised. These representations will be contrasted with how the autonomy of animals is typically socially and politically controlled. We will then analyse the characterisation of the Animal Liberation Front (ALF) - a social resistance movement that engages in non-violent direct action on behalf of animals - in both of these sources to assess how the inclusion, and even heroism, of the ALF is emphasised, in contrast to how the ALF is presented in mainstream social discourse. Further, because animal industries are increasingly concealed, we will also examine the importance of using both film and literature to bring viewers and readers to the locations and realities of institutionalised animal exploitation, such as laboratories and slaughterhouses. By making the twenty-first century experience visible, Okja and We Are All Completely Beside Ourselves each challenge modern conceptualisations of animals and our relationships with them.

Throughout the paper, in order to analyse the relationships between humans and animals that are present within media, we will be using a CAMS framework. CAMS is a critical cross-disciplinary

\footnotetext{
${ }^{1}$ The term 'animal' will be used throughout the paper to refer to non-human animals. We acknowledge that we are all indeed animals, and that humans are merely a different animal species. However, for simplicity and clarity, we will use the term animal hereafter.
} 
field, one which draws heavily on critical cultural and feminist studies, with a specific focus on understanding the power dynamics present within media representations (Merskin 2015). This field of study aims to illuminate the numerous ways in which animals are portrayed as objects, commodities, and symbols within media, and how these representations hold consequences for the real lived experiences of animals in the world (Merskin 2015) - because, as Debra Merskin notes, 'how we image other animals is a key factor in how we (mis)understand them' $(2015,19)$. Mainstream media coverage typically emphasises the status quo constructions of animals, normalising their treatment and positionality, while silencing, excluding, or ignoring them - an act which, as Nik Taylor (2015) explains, is one of structural violence. This representation of animals is one rooted within a corporatist-capitalist agenda (Taylor 2015). The potential promise of a CAMS framework is one of looking at how media can also change this narrative. Rather than creating further distancing and ignorance of animal interests, the space between the audience and the portrayal of animals, whether on screen or written on a page, can be, as Barbara Creed argues, an "ethical space that gives rise to a "creaturely" gaze with the potential to break down boundaries, to affirm communicability, between human and non-human animals' $(2004,17)$. This is why the depiction of animals, along with human and non-human animal relationships, within We Are All Completely Besides Ourselves and Okja are so significant.

Karen Joy Fowler's We Are All Completely Besides Ourselves is the story of the Cookes, who raised a chimpanzee as a member of their family. Narrated by Rosemary Cooke, the novel traces the experiences of Rosemary and her brother Lowell as they grow up with their chimp sister Fern. When Fern is sent away after displaying 'aggressive' behaviour, the family is left in a state of grief and silence that punctuates their lives thereafter. Uncovering the truth of where Fern is sent, a medical research facility, Lowell's life course dramatically changes. Leaving his family behind, he dedicates his life, and risks his freedom, as a member of the ALF to uncover the hidden truths about animals in our world.

In Bong Joon-ho's Okja, Mija (Ahn Seo-hyun) lives with her grandfather (Byun Hee-bong) and her friend Okja, a 'super pig', in the mountains of Korea for ten years before it is revealed that Okja belongs to the Mirando Corporation. When Okja is taken away as the best 'super pig' to be unveiled in New York City, Mija embarks on a quest to save her friend before she is slaughtered. Mija is aided in her mission by members of the ALF who aim to expose what the 'super pig' competition attempts to hide. The Mirando Corporation is led by CEO Lucy Mirando (Tilda Swinton) who, together with her sidekick veterinarian Dr. Johnny Wilcox (Jake Gyllenhaal), showcase how the human obsession with power and profit inherent in capitalism has dramatically changed our relationship with animals.

\section{Human and Animal Relationships}

The portrayal of animals in film and literature often reinforces human superiority and speciesist ideology by neglecting the autonomy, emotional experiences and desires of animals. Speciesism, according to Oscar Horta, is 'the unjustified disadvantageous consideration or treatment of those 
who are not classified as belonging to one or more [privileged] species' $(2010,244)$. There is an apparent and imposed ideological human and animal dualism and hierarchical order in literature and film that Adam Weitzenfeld and Melanie Joy (2014) suggest is pervasive in the Western world, and is in itself an act of speciesism. A product of society and human ideology, film and literature are anthropocentric, maintaining the centrality of human existence through the subordination or neglect of animal interests (Weitzenfeld and Joy 2014), and reinforcing the speciesist belief that animals are 'bodies not beings' (Freeman 2015, 180).

In response to these normalised media representations of animals, CAMS is used to interrogate questions such as how do representations of animals other than humans impact the lives of real animals? And what can we learn about ourselves by looking through the lens with which we look at other animals? (Merskin 2015, 12). Media has been identified by CAMS scholars as a place where the sentience of animals is routinely denied and where the status quo of animal oppression is reinforced (Freeman 2015). As Claire Molloy argues, media discourses about animals 'play a role in the normalization of particular practices and relations' $(2011,13)$. In contrast, Okja and We Are All Completely Beside Ourselves offer differing narratives about animals and their allies that challenge normalised conceptions of animals in media.

In We Are All Completely Beside Ourselves, it is not until p. 77 that readers find out that Rosemary's sister Fern is in fact a chimp. Before this point, Fern had been referred to as a family member who Lowell loves dearly, a mischievous playmate, and a sister who mysteriously disappeared. The revelation that Fern is a wild animal is partly a surprise because of the confident use of familial language that convinces us otherwise. Through Rosemary, Fowler suggests that this tactic was undertaken purposefully, so that readers did not get the impression that Fern was simply 'the family dog' when she was actually 'Lowell's little sister, his shadow, his faithful sidekick' $(2013,78)$. This sentiment suggests that the bond that Rosemary and Lowell share with Fern is so deep that classifying Fern as a member of her own species earlier on would have risked dismissal from a humanist bias. Instead of occupying a familiar space below humans, as the nameless 'family dog' does, there is a level of equality that Fowler establishes between Rosemary and Fern, 'two daughters' who were loved the same (Fowler 2013, 58). This equalisation makes it difficult to comprehend, for both Lowell and Rosemary especially, that Fern is the property of a primate research facility; that she can be bought, sold, taken away, and experimented on without consequence.

Fowler's deliberate individualisation of Fern, as someone of equal consideration, challenges the generic and anthropocentric homogenisation of animals that is typically present in media discourse (Freeman 2015). Carrie P. Freeman found that journalists, as well as animal industries, continually refer to animals as having a generic mass identity without personal attributes in order to highlight their usefulness to humans instead of their individual personalities or interests $(2015,176)$. Fowler's distinction insinuates that Fern, and perhaps even all animals who are used for research, such as the hooded rats that Lowell liberates from his father's lab, are worthy of moral consideration. Instead of merely being viewed as a research subject, one who the vast majority of 
the world will never see, hear, or know, Fern is instead someone with personhood. One of the most devastating displays of Fern's individual capacity is when Lowell finds her in Dr Uljevik's lab and Fern desperately signs to her brother 'Fern is a good girl. Please take me home now. I'll be good. I promise I'll be good' (Fowler 2013, 208). In contrast to the strict non-anthropomorphisation of animals that is an unwritten rule of science (Franco 2013), Fowler displays Fern with a complex subjectivity.

Like Fowler, Joon-ho showcases multiple contrasting relationships with animals and humans in his work, as well as a depth of character in Okja the 'super pig', that challenges a normative representation of those who are considered 'farmed' animals within the animal industrial complex. Anthropologist Barbara Noske (1997) coined the term 'animal industrial complex' to explain the intersecting interests of those responsible for the institutionalisation of animal exploitation and animals being reduced to productive machines. From the very beginning of Okja, it is evident that Okja and Mija are not a machine and an operator, but that they share a special bond. To Mija, Okja is a member of her family, just as much as her grandfather. It is unacceptable to Mija, in the same way it is unacceptable to Lowell and Rosemary with Fern, when it is revealed that Okja is actually considered property. Once Okja has been depicted as the playful, intelligent and loyal individual she is, it is also disturbing for us to learn this; that to the Mirando Corporation, Okja is nameless flesh who most importantly, needs 'to taste fucking good' (Okja 2017, 5:15).

The fact that animals are essentialised into emotionless objects, or are classified as mere parts of their bodies - wings, loin, breast, leg - is a socially and politically-constructed phenomenon that has been widely studied, in particular by feminists (Adams 1990; Birke and Parisi 1999; Fitzgerald and Pellow 2014). The deconstruction of animals into 'others"' is what allows animals to be treated, and represented, as inanimate objects whose worthiness is measured only by their utilitarian function to humans (Boggs 2011; Birke and Parisi 1999; Lee 2008). In Okja, the Mirando Corporation is a quintessential example of the oppressive capitalist culture and society that produces this essentialisation; a dynamic that is reinforced in the film through realistic interpretations of the relationships between humans and animals in the modern world. Narcissistic veterinarian Dr. Johnny Wilcox, for example, is more concerned with his own fame and fortune than the animals under his so-called care. Likewise, as the head of the Mirando Corporation, Lucy's quest to rid the world of hunger by creating a 'super pig' supersedes any shred of empathy for the individual animals or humans, like Okja and Mija, who are collateral damage in her scheme. Further, the scenes of cheering people who want to view Okja, and eat her, illustrate that the oppression of animals is not a type of violence that is inflicted by a few rogue psychopaths, but by an entire system. A critical animal perspective demands that society look beyond individual harms to animals to understand how institutionalised animal cruelty is considered socially acceptable (Fitzgerald and Pellow 2014) and how these narratives are reproduced and challenged (Merskin 2015). The most dramatic and realistic depiction of this is among the final scenes of the film, set within the walls of a slaughterhouse. 
Although the majority of people will never see the inside of a slaughterhouse, Joon-ho brings Mija, and his audience, into the bright lights of what he calls a 'metallic empire' (as quoted in Niazi 2017). Images of flesh on conveyor belts, sounds of tools that dismember hanging corpses, and the look of shock on Mija's face, convey the truly horrifying reality for countless 'farmed' animals around the world. Joon-ho described his own experience of being inside a slaughterhouse for preliminary research as 'shocking and traumatic', so much so that turning to veganism after the experience seemed like 'an instinctual physical reaction' (as quoted in Niazi 2017). The insides of factory farms, slaughterhouses, and laboratories reveal an invisible industrial war against animals (Boggs 1999; Taylor 2013; Wadiwel 2015).

This war against animals is systemic and institutionalised, but it is also a war that is veiled and hidden. Timothy Pachirat (2013), in his book Every Twelve Seconds: Industrialized Slaughter and the Politics of Sight, discusses this hidden war against animals, the powers of visibility and invisibility, and the 'politics of sight' in a gut-wrenchingly detailed account of the inner workings of a slaughterhouse. Pachirat, a researcher who took a job at a slaughterhouse for six months, recounts the horrors of the industry, both from the perspective of the animals within the system as well as the workers, and he highlights the ways in which slaughterhouse workers have to try to distance themselves from the industrialised killing in order to continue to do the work. As Pachirat describes, the contemporary slaughterhouse is 'a place that is no-place, physically hidden from sight by walls and socially veiled by the delegation of dirty, dangerous and demeaning work to others tasked with carrying out the killing, skinning and dismembering of living animals' (2013, 3-4). His work was an attempt to make the invisible visible, and he outlines the concept 'politics of sight' as the 'embodiment of organized, concerted attempts to make visible what is hidden and to breach, literally or figuratively, zones of confinement in order to bring about social and political transformation' (Pachirat 2013, 15). Because, as Paula Young Lee notes, 'to look into the slaughterhouse is to confront the problem of human-animal relations' $(2008,242)$.

Therefore, bringing the visceral secrets of the animal industrial complex into the mainstream is a significant illustration of the oppressive relationship that the capitalist system has created between humans and animals, creating necessary discomfort in those who watch or read (Colling, Parson and Arrigoni 2014). In the name of production and capital, the animal industrial complex has created a 'treadmill of production' that has transformed animals, such as pigs, chickens and cows, into largely invisible commodities (Fitzgerald and Pellow 2014). Once we get to know Fern and Okja, there is a sense of injustice over the normative treatment of these animals that largely happens without scrutiny, and without attention to the resistance of the animals themselves within the animal industrial complex. This injustice is what motivates Mija, Lowell, and other members of the ALF to ultimately fight back.

\section{Animal Allies and Antagonists}

In both Okja and We Are All Completely Beside Ourselves, the ALF is not only present, but central to the narrative. They are emphasised as key figures in the storylines and, generally speaking, are 
portrayed in a positive, if not heroic, light; a vast distinction from how the ALF is characterised within mainstream social discourse. At the same time, and as will be discussed, those involved in the animal industrial complex are also represented in a rather contrasting view to the mainstream discourse. They are not presented as ethical, honest and caring, but rather as manipulative, exploitative, and simply driven by profit and recognition.

The ALF is commonly understood as a fringe movement, taking part in more radical tactics falling outside of the mainstream animal rights movement. The ALF is an underground resistance movement, consisting of small independent and anonymous groups all over the world that promote and carry out non-violent direct action against animal exploitation industries. The ALF is not an organisation; rather, it is any dedicated individual or group who takes direct action on behalf of animals while following the ALF's four nonviolent guiding principles:

(1) To liberate animals from places of abuse (e.g. laboratories, factory farms, and fur farms) and place them in good homes where they may live out their natural lives, free from suffering;

(2) To inflict economic damage to those who profit from the misery and exploitation of animals; (3) To reveal the horror and atrocities committed against animals behind locked doors by performing nonviolent direct actions and liberations; (4) To take all necessary precautions against harming any animal, human and nonhuman (Animal Liberation Front 2005).

Often acting under the cover of night, ALF activists, donning balaclavas, and driven by the urgency for compassion and justice, willfully break the law; they are the modern-day freedom fighters risking their own freedoms in order to liberate animals from their suffering (Best and Nocella II 2004). Throughout the ALF's history, they have cost the animal exploitation industries hundreds of millions of dollars (North American Animal Liberation Press Office n.d.), and exposed the abuses taking place behind closed doors. The ALF was successfully raising awareness and posing fundamental challenges to the animal industrial complex, so in order to protect their businesses and profits, corporations needed to try to demonise activists to the general public, and they did so through the influence of language (Potter 2018). In 1985, industry groups got together and invented a new word to target and vilify these activists: ecoterrorist (Potter 2018). As Will Potter maintains, 'They knew that if they could control the terms of the debate, then they could shift public perception of these activists so that we no longer saw them as "heroes" or "warriors" [...] Instead, the public would call them terrorists" $(2018,881)$. Today, animal industries, corporations and lobbyists, corporate media, and government all continue to use this rhetoric, fear-mongering, and terrorist legislative targeting of activists in an attempt to control the conversation about the realities of animal exploitation industries and those who are speaking out on the behalf of animals (Potter 2018; Sorenson 2016). As John Sorenson claims, 'The idea that ecoterrorism is a serious danger is a social and political construction developed to protect the animal industrial complex from its critics' $(2016,44)$.

Animal activists, those who advocate for compassion and liberate animals from suffering, are deemed violent terrorists, but those who take part in the horrific abuse and killing of animals, all of which is standard within animal industries, are not (Lovitz 2011; Sorenson 2009; Sorenson 
2016). This violence-framing is extensively used in representations of animal activists, despite the fact that most of the actions undertaken by the animal rights movement are cases of property damage, breaking and entering, and the rescuing of animals, and in spite of the fact that these movements have never harmed a single person (Lovitz 2011; Potter 2018; Salter 2011; Sorenson 2016). Yet, those involved within the animal industrial complex continue to claim that they are under attack by violent extremists, a portrayal that is maintained by government and majority ideologies (Lovitz 2011; Sorenson 2009; Sorenson 2016).

In $O k j a$ we see, perhaps for the very first time, one of the most accurately-depicted representations of the ALF in a mainstream film. While there are some minor discrepancies presented within the film regarding the ALF and their adherence to nonviolence, the general portrayal of these activists, and those who oppose them, is predominantly in line with how the ALF promotes themselves, and one cannot deny the overall generally noble depiction of the ALF throughout. We are first introduced to the ALF in Seoul, South Korea, after Okja has been taken away from Mija and the ALF arrive to try and liberate Okja as she is being transported. As the ALF members pull up beside the truck with Okja inside, activist K (Steven Yuen) announces to the driver Kim (Choi Woo-shik) and Mirando employee Mundo Park (Yoon Je-moon), 'Nice to meet you. We're not terrorists! We don't like violence. We don't want to hurt you. Stop the truck!' (Okja 2017, 41:16). As the ALF manages to intercept the truck and works to free Okja, Mundo calls the police for help, stating 'Terrorists! There are terrorists here!' (Okja 2017, 42:56). In subsequent scenes, we again see the ALF activists decrying the idea that they are violent. They are seen telling Mija that they are good people and that they are on her side. In their attempts to protect Okja from the police, the activists apologise for any harm they may have caused them: 'So sorry if we hurt you. It wasn't our intention' (Okja 2017, 47:57). What follows, in a perhaps unprecedented mainstream depiction, is a scene where director Joon-ho explicitly features a thorough, detailed, and precise explanation of who the ALF are. Using real-life photographs of the ALF in action along with liberated animals, activist Jay (Paul Dano) explains to Mija what the ALF are about:

We are animal lovers. We rescue animals from slaughterhouses, zoos, labs. We tear down cages and set them free. This is why we rescued Okja. For forty years, our group has liberated animals from places of abuse. We inflict economic damage on those who profit from their misery. We reveal their atrocities to the public and we never harm anyone, human or non-human. That is our forty-year credo. (Okja 2017, 50:38).

This, according to the ALF's history and own guidelines, is not only an accurate portrayal, but it represents the movement using their own explicit message and code. To see the ALF depicted in a mainstream film, in such a truthful way, essentially in their own words, is something that all who support the ALF can rejoice in.

Throughout Okja, we continue to see animal industry representatives labelling the ALF activists as violent terrorists, and often claiming to be victimised by the activists themselves. Lucy exclaims, 'I know what they are calling me, those ALF fuckers, they are calling me a psychopath!', (Okja 2017, 1:00:36) to which a Mirando associate responds 'They are the psychopaths. They are narcissists.' Lucy continues, 'We get tangled up in this terrorism thing and suddenly we end up 
being the ones who look bad' (Okja 2017, 1:03:03). This shift of focus and blame from their own behaviour to that of the activists reflects the purpose of the 'ecoterrorist' label and how it functions in the real world; corporate villainisation of activists in the public eye in order to save their own public image. While there is no evidence to support such terrorist labelling of activists, the term is consistently used to 'segment ideas, without engagement with the socio-political basis for the actions of those targeted' (Salter 2011,219) - a prevalent theme we see throughout the entirety of the film.

While mainstream discourse promotes the idea that animal industries are honest, humane and ethical, in $O \mathrm{kja}$, Joon-ho depicts a very different reality of the animal agriculture industry. Lucy is presented as perfectly manufactured; she has perfected the outside image not only of herself, but of the new era for the Mirando Corporation, a new era founded on so-called ethics and sustainable business practices. Throughout the film, however, we find out that Lucy is as unhinged as her business plans, using marketing to deceive her consumers about their practices, and more concerned about her image and profit than the 'core values' her company allegedly stands for. In contrast, Dr Johnny Wilcox is presented as a disheveled, hypocritical, tormented industry veterinarian, who at times seems to be struggling with his role in the exploitation of the 'super pigs', while at others, is merely concerned with his public persona and fame. Nancy Mirando, Lucy's sister, is portrayed as uncompassionate, cold and merely profit-driven, referring to Okja as 'it', repeatedly calling Okja her property, and telling Mija bluntly that they can only sell the dead ones - 'It's all edible except the squeal' (Okja 2017, 1:44:32). Through his character development in the film, Joon-ho pulls back the curtain on an industry built on mistruths and manipulation (Almiron 2015), exposing viewers to the reality of the animal industrial complex, those who work within it, and those who oppose it. This crucial character development, truthful representation of the ALF, and vivid spotlight on animal industries, are only further exemplified within the book $W e$ Are All Completely Beside Ourselves.

As in Okja, noble depictions of the ALF are also prevalent throughout We Are All Completely Beside Ourselves. Fowler spares no details in her accurate descriptions of how and why the ALF operates, or how the ALF is deemed a domestic terrorist threat. She even provides real-life historical context, referencing the first documented ALF action in the United States with the release of two dolphins from the University of Hawaii (Fowler 2013). Outlining the horrendous treatment of animals within the animal industrial complex, Fowler explicitly sets the stage for an undeniable understanding of the purpose of the ALF.

Throughout the book, Fowler also notes, numerous times, how ALF actions are deemed domestic terrorism by the FBI. The use of the term 'terrorist' is an interesting one, as definitions of the term number in the hundreds, with no single agreed-upon definition (Lovitz 2011). Terrorism discourse and legislation is therefore 'plagued by confusion and misrepresentation' (Sorenson 2009, 237). The absurdity of such labelling of activists is also emphasised in the book, and is evident when Rosemary, explaining Lowell's arrest by the FBI, notes, 'An attack on SeaWorld might mean a bomb, or it might mean graffiti and glitter and a cream pie in the face. The government doesn't 
always seem to distinguish between the two.' (Fowler 2013, 304). Not only does Fowler characterise the ALF accurately and highlight the terrorist labelling of activists, she also, importantly, raises the issue of real-life activist repression in the form of what are known as 'aggag' laws: 'A number of states are considering laws that make the unauthorized photographing of what goes on in factory farms and slaughterhouses a felony. Making people look at what is really happening is about to become a serious crime.' (Fowler 2013, 238). Exposing the industry is therefore a crime, but the industry abuses themselves are not (Potter 2018; Sorenson 2009; Sorenson 2016).

Like Okja, We Are All Completely Beside Ourselves depicts an opposing reality to mainstream ideologies around animal industries and specifically the animal experimentation industry and those who work within it. Fowler describes in detail many instances of the horrific suffering animals endure under the guise of science, including the real-life case of Britches, a baby macaque monkey who was taken from his mother at birth and had his eyelids sewn shut in order to test an electronic sonar device, and who was eventually liberated by the ALF in 1985. As Rosemary explains this case, she notes, 'I didn't want a world in which I had to choose between blind human babies and tortured monkey ones. To be frank, that's the sort of choice I expect science to protect me from, not give me.' (Fowler 2013, 141). Throughout the book, animal exploiters are not depicted as caring, misunderstood, ethical individuals just doing a job, but rather, they are seen as troubled, even evil, and only out to make a profit. In a description of her own father and his treatment of animals as a scientist, Rosemary claims 'My father was kind to animals unless it was in the interest of science to be otherwise. He would have never run over a cat if there was nothing to be learned by doing so.' (Fowler 2013, 92). Dr Uljevik, who was in control of the lab where Fern ended up, is described as less of a scientist than a supervillain, as someone who gained pleasure out of dominating animals, and 'the kind of scientist who belongs in a prison for the criminally insane' (Fowler 2013, 214). These are not merely individuals who are misconstrued and falsely targeted by activists; these are individuals actively engaged in the exploitation and physical and mental torture of animals.

The award-winning film and best-selling novel push open the door to a world that many are not privy to: the world of animal liberation. In a rare, if not unparalleled depiction of animal activism in literary fiction, Fowler describes Lowell's life, his work uncovering the truths in factory farms and laboratories, as a result 'of his very best qualities, of our very best qualities - empathy, compassion, loyalty and love. That needs to be recognized.' $(2013,307)$. Similarly, in Okja, when the ALF is attempting to liberate Okja from her 'big reveal' in New York, hundreds of people from the audience pull out balaclavas and jump on stage to rescue her as part of the ALF action, illustrating that perhaps this is not a fringe movement or a few extremists after all, but a more popular and almost mainstream ideology.

By highlighting both animal subjectivity and activist resistance in their work, Joon-ho and Fowler also create another subjectivity: the witness. Their audiences are ultimately bearing witness. Actively witnessing the suffering and plight of animals, and sharing their stories, is very much a 
political act of resistance, one that ensures that the erasure of those lives cannot fully take place. The visibility created by Joon-ho and Fowler highlights the oppression and suffering that takes place and engages us on an emotional level that has transformative potential. This is the significance of these media sources' ground-breaking representations of the ALF and the animal industrial complex, as they challenge normative ideas about animals in contemporary society. As Merskin argues, 'Vital to our understanding of media is identifying the power of images and words to either reveal or conceal' $(2015,20)$. In addition, the language employed in these media sources is also a compelling method to examine human and animal representation.

\section{Animal Rhetoric}

Language is also a pivotal theme in both Okja and We Are All Completely Beside Ourselves, and it is one that emphasises and challenges the dynamics between humans and animals. Research by Amy Fitzgerald and Nik Taylor (2014) reveals that the subjugation of animals can be discerned through discursive mediums. That is, commonly held beliefs about both animals, and humans can be understood through discourse. An example of this was discussed previously - the ALF is commonly identified as ecoterrorist, or as dangerous and violent, by government institutions in order to delegitimise their cause, regardless of a lack of evidence to prove this. Language was also acknowledged regarding the individualisation of Fern and Okja that Fowler and Joon-ho display. The power to name has the effect of producing a subjectivity that is in contrast to the broad generalisation of animals as 'others'. Naming also illustrates a cognitive dissonance of celebrating an individual animal, such as the popular children's show Peppa Pig, while billions of animals distanced on farms are killed each year (Colling, Parson and Arrigoni 2014). The scene in Okja, of Mija, Jay, and K running through the pen of 'super pigs' searching for Okja, while ignoring the others, highlights this dissonance. Language is therefore a powerful tool that can influence how people know, think about, and relate to animals.

One of the most prolific methods of language usage in relation to the oppression of animals is the rhetoric used to sell animal bodies (Hannan 2020). This is exemplified in the opening scenes of Okja, when Lucy is describing the 'super pig' project while words like 'eco-friendly', 'natural' and 'non-GMO' are projected on the screen behind her (Okja 2017, 2:58). In an effort to disguise the genetic manipulation of engineering a 'super pig', Lucy deliberately presents Mirando's project as 'Mother Nature's gift' in an almost childlike fashion, claiming that her core values are 'environment' and 'life' (Okja 2017, 1:15). In their research of meat and dairy advertisements, Fitzgerald and Taylor (2014) found that the word 'natural' was used to legitimise the use of animals based on the notion that nature is a resource. This is similar to the classification of different animals as either companion animals, as wild, as food or as research subjects, like Fern. The superiority of humans is a hegemonic principle of anthropocentrism and imperialism that has become normalised in animal discourse (Weitzenfeld and Joy 2014). Further, emphasising words such as 'environment' or 'natural' distracts from the industrial conditions in which most animals in the Western world are raised (Fitzgerald and Taylor 2014). The tongue-in-cheek rhetoric in Okja, 
exemplified by Lucy, mirrors the efforts by the animal agriculture industry, in concealing or redressing the plight of animals who are entrenched within the agricultural system.

Believing the 'little white lies', as Lucy puts it, is part of the fallacy that pigs and cows want to be turned into Oscar Meyer wieners, that chickens want to give us their wings and that rabbits wish to 'collaborate' with researchers (Davis 2011). In his book The Emotional Lives of Animals, Marc Bekoff shares a quote by John Capitanio, associate director of a primate research facility, who said animals are 'a neutral palette on which we paint our needs, feelings and view of the world' (2007, 25). Karen Davis suggests that these anthropocentric images and rhetoric from animal industries and media attempt to communicate that whatever is done to animals is in their interest, whether that is rape, mutilation, imprisonment or murder - that there is a 'genocidal erasure of an animal's true identity in favour of the abuser's image' $(2011,46)$. Images of happy animals, despite their real circumstances, and words such as 'humane' or 'free-range' have gained traction in the modern world because of increasing attention to how animals are treated in labs or factory-farm settings. However, although the language of capitalism has shifted, it is the function of the same system that justifies and normalises the instrumentalisation of non-human animal life (Almiron 2015). As Merskin argues, '[...] the symbolic and the real are connected' $(2015,14)$. Language, as conferred by symbols, diction, or a lack of communication, remains a central contemporary method of power and domination that can impact how animals are understood, and consequently treated, in the real world (Merskin 2015).

\section{Conclusion}

Using the examples of We Are All Completely Beside Ourselves and Okja, and using a CAMS framework, we have demonstrated how these specific twenty-first century media representations of animals, and animal activists, have challenged the dominant discourse and ideology that underlies human and animal relationships typically present in media sources. CAMS scholars acknowledge the role of media in influencing and informing social responses, which is why a critical examination of the anthropocentric language, images and symbols within film and literature is essential to understanding our relationship with animals. As Merskin argues, a speciesist ideology 'informs what media are made, what content they contain, and what hegemonic message they express' (Merskin 2015, 17). As a result, animals are re-presented in the aggregate, as symbols, commodities and objects (Merskin 2015). Through granting the animal protagonists in their work individual agency, Fowler and Joon-ho challenge the devaluation of animals in media. Both Fern and Okja are represented as complex individuals who resist the violence that is inherent in the animal industrial complex. Although these two animals are fictional characters, their subjectivity helps to decenter the master narrative that has hidden the real experiences of commodified animals from public view.

As scholars have rightly argued, animal oppression has largely been made invisible (Adams 1990; Boggs 2011; Pachirat 2013). The distancing of animals used for experimentation or slaughtered for consumption, from the pharmacy or the supermarket, is a concealment that allows people to 
insulate themselves from the moral arguments of animal interests - the pain and suffering of animals cannot be discerned by those so far removed from the process (Boggs 2011). In contrast, Fowler and Joon-ho bring their readers and viewers not only to the 'zones of torture' (Boggs 2011, 77) but they emphasise, and even heroise, those who are fighting for animal liberation. They provide their audiences with an opportunity to dive into the world of animal liberation, to connect and sympathise with activists, and to understand who and what the ALF are fighting for, and who they are fighting against.

As demonstrated throughout this article, the representations of the ALF within both Okja and We Are All Completely Beside Ourselves are particularly significant, as these narratives challenge the dominant discourse around the ALF and animal industries in mainstream media. Viewers and readers are exposed to the reality that animal activists are not violent criminals or terrorists, but compassionate individuals, motivated by empathy, love and justice, using direct action to liberate animals from suffering. In a world where animal activists are villainised, these media sources do the opposite; they highlight the inconsistencies in this unfounded characterisation, exposing the true goals and actions of activists, and uncovering the reality of the suffering that takes place within the animal industrial complex. These mainstream media representations provided a location in which animal suffering and individuality, along with a realistic depiction of activist intentions, are finally made visible.

\section{References}

Adams, C. J. (1990) The Sexual Politics of Meat: A Feminist Vegetarian Critical Theory. New York: The Continuum Publishing Company.

Almiron, N. (2015) 'The Political Economy Behind the Oppression of Other Animals: Interest and Influence', in Almiron, N., Cole, M., and Freeman, C.P. (eds.) Critical Animal and Media Studies: Communication for Nonhuman Animal Advocacy. New York: Routledge, pp. 26-41.

Animal Liberation Front (2005) 'ALF Guidelines', No Compromise, 30.

Bekoff, M. (2007) The Emotional Lives of Animals. California: New World Library.

Best, S., and Nocella II, A. J. (2004) 'Behind the Mask: Uncovering the Animal Liberation Front', in Best, S., and Nocella II, A. J. (eds.). Terrorists or Freedom Fighters?: Reflections on the Liberation of Animals. New York: Lantern Books, pp. 9-63.

Birke, L. and Parisi, L. (1999) 'Animals, Becoming', in H.P Steeves (ed.), Animal Others: On Ethics, Ontology and Animal Life. New York: Suny Press, pp. 55-73.

Boggs, C. (2011) 'Corporate Power, Ecological Crisis, and Animal Rights', in J. Sanbonmatsu (ed.), Critical Theory and Animal Liberation. Washington: Rowman and Littlefield Publishers, pp. 71-96.

Colling, S., Parson, S. and Arrigoni, A. (2014) 'Until All Are Free: Total Liberation Through Revolutionary Decolonization, Groundless Solidarity, and a Relationship Framework', in 
Nocella II, A. J., Sorenson, J., Socha, K., and Matsuoka, A. (eds.) Defining Critical Animal Studies: An Intersectional Social Justice Approach for Liberation. New York: Peter Lang, pp. 51-73.

Creed, B. (2014) 'Animal Deaths on Screen: Film and Ethics', Relations, 2(1), pp. 15-31.

Davis, K. (2011) 'Procrustean Solutions to Animal Identity and Welfare Problems', in J. Sanbonmatsu (ed.) Critical Theory and Animal Liberation. Washington: Rowman and Littlefield Publishers, pp. 35-53.

Fitzgerald, A.J. and Pellow, D. (2014) 'Ecological Defence for Animal Liberation: A Holistic Understanding of the World', in Nocella II, A. J., Sorenson, J., Socha, K., and Matsuoka, A. (eds.) Defining Critical Animal Studies: An Intersectional Social Justice Approach for Liberation. New York: Peter Lang, pp.28-48.

Fitzgerald, A.J and Taylor, N. (2014) 'The Cultural Hegemony of Meat and the Animal Industrial Complex', in Taylor, N. and Twine, R (eds.) The Rise of Critical Animal Studies: From the Margins to the Centre, New York: Routledge, pp. 165-182.

Fowler, K. J. (2013) We Are All Completely Beside Ourselves. New York: G.P Putnam’s Sons. Franco, N. H. (2013) 'Animal Experiments in Biomedical Research: A Historical Perspective', Animals: An Open Access Journal from MDPI, 3(1), pp. 238-273.

Freeman, C. P. (2015) 'This Little Piggy Went to Press: The American News Media's Construction of Animals in Agriculture', in Almiron, N., Cole, M., and Freeman, C.P. (eds.) Critical Animal and Media Studies: Communication for Nonhuman Animal Advocacy. New York: Routledge, pp. 169-184.

Hannan, J. (ed.) (2020) Meatsplaining: The Animal Agriculture Industry and the Rhetoric of Denial. Sydney: Sydney University Press.

Horta, O. (2010) 'What is Speciesism?', Journal of Agriculture and Environmental Ethics, (23), pp. 243-266.

Okja (2017) Directed by B. Joon-ho. [Feature film]. Netflix/Next Entertainment World.

Lee, P. (ed.) (2008) Meat, Modernity, and the Rise of the Slaughterhouse. New Hampshire: University Press of New England.

Lovitz, D. (2011) Muzzling a Movement: The Effects of Anti-Terrorism Law, Money and Politics on Animal Activism. New York: Lantern Books.

Malloy, C. (2011) Popular Media and Animals. London: Palgrave Macmillan.

Merskin, D. (2015) 'Media Theories and the Crossroads of Critical Animal and Media Studies', in Almiron, N., Cole, M., and Freeman, C.P. (eds.) Critical Animal and Media Studies: Communication for Nonhuman Animal Advocacy. New York: Routledge, pp. 11-25. 
Niazi, A. (2017) '’Okja" used a mutant super pig to link capitalism and consumption', Vice, 28 June. Available at: https://www.vice.com/en/article/vbg55x/okja-used-a-mutant-super-pig-tolink-capitalism-and-consumption (Accessed: 14 November 2020).

North American Animal Liberation Press Office. (n.d.) Background. Available at: https://animalliberationpressoffice.org/NAALPO/background/ (Accessed: 18 November 2020).

Noske, B. (1997) Beyond Boundaries: Humans and Animals. Quebec: Black Rose Books.

Pachirat, T. (2013) Every Twelve Seconds: Industrialized Slaughter and the Politics of Sight. Connecticut: Yale University Press.

Potter, W. (2018) 'Sentinel Species: The Criminalization of Animal Rights Activists as "Terrorists" and What it Means for Civil Liberties in Trump's America', Denver Law Review, 95(4), pp. 877-907.

Salter, C. (2011) 'Activism as Terrorism: The Green Scare, Radical Environmentalism, and Governmentality', Anarchist Developments in Cultural Studies, 1, pp. 211-238.

Sorenson, J. (2009) 'Constructing Terrorists: Propaganda About Animal Rights', Critical Studies on Terrorism, 2(2), pp. 237-256.

Sorenson, J. (2016) Constructing Ecoterrorism: Capitalism, Speciesism, and Animal Rights. Nova Scotia: Fernwood Publishing.

Taylor, C. (2013) 'Foucault and Critical Animal Studies: Genealogies of Agricultural Power', Philosophy Compass, 8(6), pp. 539-551.

Taylor, N. (2015) 'Suffering is Not Enough: Media Depictions of Violence to Other Animals and Social Change', in Almiron, N., Cole, M., and Freeman, C.P. (eds.) Critical Animal and Media Studies: Communication for Nonhuman Animal Advocacy. New York: Routledge, pp. 42-55.

Wadiwel, D. (2015) The War Against Animals. Leiden: Brill.

Weitzenfeld, A. and Joy, M. (2014) 'An Overview of Anthropocentrism, Humanism and Speciesism in Critical Animal Theory', in Nocella II, A., Sorenson, J., Socha, K., and Matsuoka, A. (eds.) Defining Critical Animal Studies: An Intersectional Social Justice Approach for Liberation. New York: Peter Lang, pp. 3-27. 
Tayler Zavitz is a $\mathrm{PhD}$ candidate, sessional instructor, teaching assistant consultant, and teaching assistant in the Sociology department at the University of Victoria. Her research is funded by the Social Sciences and Research Council of Canada and focuses on the historical and current repression of animal activism in Canada and the expanding criminalisation of dissent. She holds a Master's degree in Critical Sociology, with a focus in Critical Animal Studies, from Brock University. She is a collective member of the North American Association for Critical Animal Studies, social media coordinator for the Animals \& Society Research Initiative at the University of Victoria, and peer reviewer for the Journal for Critical Animal Studies.

Email: tstaneff@uvic.ca

Corie Kielbiski is a Master's student and teaching assistant in the Political Science department at the University of Victoria on the unceded territory of the Lekwungen peoples. Her research is funded by the Social Sciences and Research Council of Canada and focuses on historical injustice and the politics of memory with specific attention on municipal governance and statue removals. She holds a Bachelor of Arts Degree in Political Science and English with distinction from the University of Victoria. Corie is a researcher with the Animal Alliance of Canada, a co-founder of the Vancouver Island Vegan Association and a dedicated animal advocate in her community.

Email: coriekielbiski@uvic.ca 